\title{
$\mathrm{X}$ 線粉末プロファイル法による炭化ケイ素の積層不整の定量方法
}

\author{
立山＼cjkstart博・須藤信 行*・村川紀 博* \\ $\left(\begin{array}{c}\text { 九州工業技術試験所, } 841 \text { 佐賀県鳥栖市宿町 } \\ * \text { 三井東圧化学 (株), } 750 \text { 山口県下関市彦島迫町 7-1-1 }\end{array}\right)$
}

\section{Quantitative Analysis of Stacking Faults in the Structure of SiC by X-Ray Powder Profile Refinement Method}

\author{
Hiroshi TATEYAMA, Nobuyuki SUTOH* and Norihiro MURAKAWA* \\ $\left(\begin{array}{ccc}\text { Government Industrial Research Institute, Kyushu, Shuku-machi, Tosu-shi } & 841 & \\ * \text { Mitsui Toatsu Chemicals, Inc., 1-1-7, Hikoshima Sako-machi, Shimonoseki-shi } & 750\end{array}\right)$
}

\begin{abstract}
Submicron powders of $\mathrm{SiC}$ were synthesized at different temperatures $\left(1700^{\circ}-2000^{\circ} \mathrm{C}\right)$ by reaction of a mixed powder of carbon and silicon dioxide prepared by the spray thermal decomposition method. The structural and quantitative analyses of the synthesized SiC were carried out using the Rietveld method on the basis of the cubic and hexagonal close packed models. The calculated X-ray powder profiles, however, did not coinside with the experimental patterns. The disagreement seemed to be due to the fact that synthesized SiC includes stacking faults. A general method for calculating the X-ray powder profiles by matrices was developed for the quantitative analysis of stacking faults in the SiC structure. The profile calculated on the basis of Paterson model showed that the peak of (102) reflection moved toward the lower angle with increasing amount of stacking faults, which was not observed in the experimental patterns. The present calculation assumed that continuing probability of positive sequence was not the same as that of negative sequence in the Wilson model. The profiles calculated on this model were in good agreement with the experimental patterns, indicating that the structure of the present SiC contained stacking faults in which the proportions of continuing probabilities were different. The values of the positive and negative continuing probabilities decreased as the synthetic temperature increased. The negative probabilitiy was always larger than that of positive one under the present synthetic conditions.

[Received May 11, 1988 ; Accepted June 24, 1988]
\end{abstract}

Key-words : Quantitative analysis, Stacking faults, Silicon carbide, X-ray powder profile refinement method, Crystal structure, Different continuing probabilities

\section{1. 緒 言}

炭化ケイ素 $(\mathrm{SiC})$ は優れた高温構造材料として各方 面で研究が進められている ${ }^{1)}$. . また最近は高強度の焼 結体を得るために高純度かつ超微粒の $\mathrm{SiC}$ 粉末の合成 が試みられている ${ }^{5) ~ 10)} . \mathrm{SiC} に は$ 多数のポリタイプ(多 形）があり，その生成温度によりポリタイプの種類が異 なるが'11), 結晶構造は大別して $\beta$ 晶（立方晶系, Ramsdell 記号 3 C) と $\alpha$ 晶 (六方晶系又は三方晶系菱面体構 造, Ramsdell 記号 $4 \mathrm{H}, 6 \mathrm{H}, 15 \mathrm{R}, 21 \mathrm{R}$, 他) の 2 種 類に分類できる ${ }^{12) ~ 14)}$. このような立方詰め込み構造と 六方詰め込み構造の両者を取り得る結晶は積層不整を起

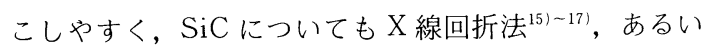
は電子線回折法 ${ }^{18), 19)}$ により積層不整の研究が行われて いる. 特に最近は高分解能電子顕微鏡の発達により直接 格子像として積層不整の存在が確認されている201 221. しかし，これらは $\mathrm{SiC}$ の局所的な解析であり, バルク の性質は表していない，特にファインセラミックス原料 として合成された $\mathrm{SiC}$ 粉末の場合にはバルクの性質の 把握が製品の品質管理上重要である.このような粉末原 料の性質を明らかにする方法としてX 線粉末法が最も
優れているが，X 線粉末法を用いて $\mathrm{SiC}$ の不整構造の 解析を定量的に行った例はない.

1969 年に中性子線回折法により Rietveld 法が開発さ れて以来 ${ }^{23)}$, 本方法を $\mathrm{X}$ 線粉末法に適用し, 各種の結 晶の構造解析が行われた 24 -27). しかし, Rietveld 法は 後述するように積層不整のない結晶にしか適用できない ため, その適用範囲に限界があった。そこで本研究では 積層不整を有する結晶についても，X線粉末法により 不整構造の解析が行えるようにX 線粉末法の基本強度 式を検討し，その基本式を基に今回合成された $\mathrm{SiC}$ 粉 末について不整構造の解析を行った.

\section{2. 実験方法}

\section{$2.1 \mathrm{SiC}$ 粉末の調製}

加水分解性ケイ素モノマーと炭素数 9 の石油留分との 液状混合物を $1000^{\circ} \sim 1200^{\circ} \mathrm{C}$ のプロパン火炎中で噴霧熱 分解し ${ }^{9 !}$, 生成したエアロゾルより固型物をバッグフィ ルターで捕集して二酸化ケイ素と炭素のすす状の混合粉 末 (比表面積 $37.4 \mathrm{~m}^{2} / \mathrm{g}, \mathrm{C} / \mathrm{SiO}_{2}$ (重量比)=1.6) を得た. この混合粉末を圧縮成形して黒鈆製るつぼ内に設置し, 
高周波誘導電気炬にて窒素ガス雾囲気中，所定温度で 30 分間加熱して合成品を得た. 合成品は余剩炭素を空 気中で $700^{\circ} \mathrm{C}, 20$ 時間加熱して燃焼・除去した後, フッ 化水素酸にて処理し, 水洗乾燥して測定用試料とした. 試料は $1700^{\circ}, 1800^{\circ}, 1900^{\circ}$, 及び $2000^{\circ} \mathrm{C}$ の 4 水準の温 度で調製した。それぞれの試料を T-A， T-B， T-C 及 び $\mathrm{T}-\mathrm{D}$ と以後呼称する. また, 上記と同様に $1600^{\circ} \mathrm{C}$ で 1 時間加熱して合成した $\mathrm{SiC}$ 粉末を窒素ガス雾囲気 中で所定温度に 30 分間再加熱した試料も調製した. 再 加熱には上記と同一の加熱炬を用い，再加熱温度は $1700^{\circ}, 1800^{\circ}, 1900^{\circ}, 2000^{\circ} \mathrm{C}$ の 4 水準とし, それぞれ の試料を $\mathrm{T}-17, \mathrm{~T}-18, \mathrm{~T}-19$ 及び $\mathrm{T}-20$ と以後呼称する.

\section{2 比表面積の測定}

$\mathrm{N}_{2}$ ガス吸着による BET 法で比表面積を測定した。

\section{$2.3 \mathrm{X}$ 線粉末パターンの測定}

フィリップス社製 APD 15 型グラファイトモノクロ メーター付き $\mathrm{X}$ 線回折装置を用いて，測定はステップ スキャン法で行い, 得られたデー夕はすべて磁気テープ に収めた。測定条件は，ステップスキャン幅：0.05， 各ステップ毎の測定時間：10 秒, 試料スピン : $150 \mathrm{rpm}$, スリット $: 1^{\circ}-1-0.3^{\circ}$, 電流・電圧 $: 20 \mathrm{~mA}, 30 \mathrm{kV}$ であ る。

磁気テープに収められたデータは，日立製作所製 HITAC $220 \mathrm{~K}$ 型電子計算機で処理し，不整構造解析の ための計算を行った。また，X 線光学系のスリットな よ゙による装置関数のパラメーターは薄片状にした白雲母 を用いて (0014) 反射のプロファイルから求めた ${ }^{28)}$. ま たピーク位置の補正はブラジル産水晶 $(3 \sim 5 \mu \mathrm{m})$ を用 いて行った。

\section{3. 計算方法}

\section{1 一般強度式}

結晶の構造解析を行う際, 結晶内の原子配列が domain 内で 3 次元的に周期的であれば通常の X 線粉末強 度式が使え，Rietveld 法 ${ }^{23)}$ により構造解析が行える。 しかし，2 次元方向での原子配列は周期性を保持してい るが，その層に垂直な方向での原子配列，すなわち層の 積み重なりが規則的でない場合（積層不整）にはRietveld 法による解析は行えない。積層不整が存在する場 合の X 線回折法による理論的考察は単結晶法により検 討された 23) 32). また，粉末法による解析は硫化チ夕 ン ${ }^{33)}$-34), カオリナイト ${ }^{35)}$, 混合層鉱物 ${ }^{36)}$ 等があるが, 主に積層不整に関係のある反射についての解析であっ た。これまで積層不整を有する結晶について，不整のあ る反射からない反射まで X 線粉末法を用いて定量的に 解析した例はない，今回はまず積層不整を含む結晶の $\mathrm{X}$ 線粉末法における一般強度式の導入を仁田 ${ }^{371}$ の式を 基に行った.
1 次元方向のみに不整を有する結晶の場合は，1 次元 不整格子の回折強度式を用いなくてはならない， $c$ 軸方 向のみ不整を考えると，その回折強度式 ${ }^{37)}$ は

$I(\xi \eta \zeta)=I_{\mathrm{e}} \Sigma(N-m)<F_{n} F_{n+m}>_{n} \exp (-2 \pi i \zeta m) L(\xi \eta)$

$$
L(\xi \eta)=\frac{\sin ^{2} \pi L \xi}{\sin ^{2} \pi \xi} \frac{\sin ^{2} \pi M \eta}{\sin ^{2} \pi \eta}
$$

となる。これを行列表示すると

$$
\begin{aligned}
& I(\xi \eta \zeta)=I_{\mathrm{e}}\left\{N V^{2}+\sum(N-m) \text { spur } V F Q^{m}+\text { conj. }\right\} \\
& Q=\Phi P
\end{aligned}
$$

ここで行列 $V$ は層構造因子 $\left(V_{\mathrm{s}}\right)$ からなる.

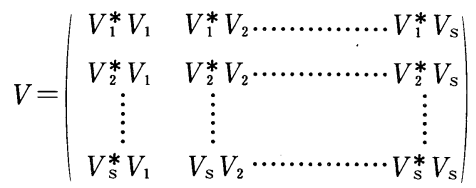

行列 $F$ は異なる層の層構造因子の存在確率 $\left(\omega_{\mathrm{s}}\right)$ から なる。

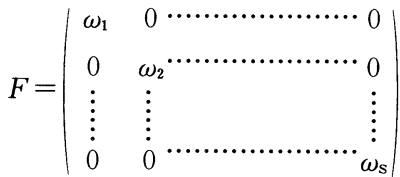

行列 $P$ はある基準層から $m$ 枚隔てて同種の層が現れる 継続確率 $\left(P_{\mathrm{pr}}\right)$ からなる.

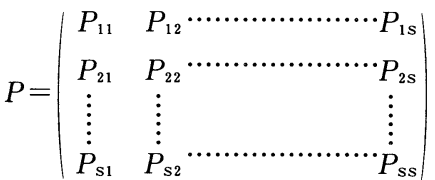

また

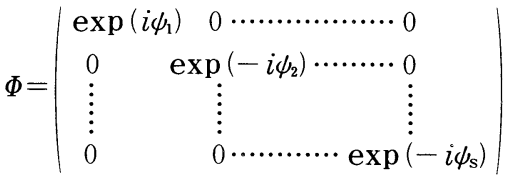

$\psi_{\mathrm{s}}$ は位相角を示し, $\psi_{\mathrm{s}}=2 \pi \mu_{\mathrm{s}} \zeta$ で表される.

この式の一般解は以下のようになる.

$$
\begin{aligned}
I(\xi \eta \zeta)= & I_{\mathrm{e}} L(\xi \eta) N\left[\left\{\sum C \nu_{0} D \nu\right.\right. \\
& +\sum(1 / N) C \nu_{0}\left(H^{1} \nu \cos \rho \nu\right. \\
& \left.\left.\left.+H^{2} \nu \sin \rho \nu\right)\right\} / L(\xi \eta)\right]
\end{aligned}
$$

$D \nu$ は散漫散乱項で以下のようになる.

$$
D \nu(\xi \eta \zeta)=\frac{\left(1-x \nu_{0}\right) \cos \rho \nu+2 x \nu_{0} \sin (2 \pi \zeta) \sin \rho \nu}{\left(1-x \nu_{0}\right)^{2}+4 x \nu_{0} \sin ^{2}(\pi \zeta)}
$$

$H^{1} \nu$ と $H^{2} \nu$ は高次の項を表す。高次の項は積層不整が 非常に小さい場合又は層の枚数 $(N)$ が少ない場合以外 は無視することができる.

$\mathrm{X}$ 線粉末法におけるラインプロファイルの式は 
$I_{\mathrm{d}}(2 \theta) \mathrm{d} 2 \theta=\sum n K P(2 \theta) R(\alpha) \frac{\lambda^{2} \Delta l}{16 \pi r^{2} \sin (\theta)} X(\zeta)$

ただし $G_{\mathrm{d}}(2 \theta)=\int G(\xi \eta) \mathrm{d} S$

ここで $G(\xi \eta)$ は $L(\xi \eta)$ のラウエ関数をガウス関数で表 したものである. $\Sigma n$ は微結晶の総数を表しており, $R(\alpha)$ は配向分布関数を表している ${ }^{38)} . X(\zeta)$ は（3) 式の [ ] の中の式を表している.

$G(\xi \eta)$ を $S$ につて積分すると

$$
\begin{aligned}
I_{\mathrm{d}}(2 \theta) \mathrm{d} 2 \theta= & \frac{K P(2 \theta) R(\alpha) \lambda^{2} \Delta V \Delta l}{8 \pi r^{2} c^{*} \sin \theta \sqrt{\sin ^{2} \theta-\sin ^{2} \theta_{0}}} \\
& \cdot X(\zeta) \mathrm{d} 2 \theta
\end{aligned}
$$

ここで $c^{*}$ は $c$ 軸方向の最小単位の大きさを表す.

また， $\theta \doteqdot \theta_{0}$ のときは以下の Warren $の$ 式 ${ }^{39)}$ に従った.

$$
\begin{gathered}
I_{\mathrm{d}}(2 \theta) \mathrm{d} 2 \theta=\frac{K P(2 \theta) R(\alpha) \sqrt{m} \lambda^{3 / 2} \Delta V \Delta l}{4 \pi^{5 / 4} r v^{2} c^{*} \sin ^{3 / 2} \theta} \\
\cdot F(a) X(\zeta) \mathrm{d} 2 \theta \\
F(a)=\int \exp \left[-\left(a-x^{2}\right)^{2}\right] \mathrm{d} x
\end{gathered}
$$

$R(\alpha)$ は配向分布関数で以下のように規格化される ${ }^{38)}$.

$$
\begin{aligned}
& R(\alpha)=\phi(\alpha) / \int 2 \pi \phi(\alpha) \sin \alpha \mathrm{d} \alpha \\
& \phi(\alpha)=P_{1}+\left(1-P_{1}\right) \exp \left(-P_{2} \alpha^{2}\right)
\end{aligned}
$$

一般に実測の X 線粉末回折パターンは X 線回折装置 の光学系の影響を受けて機械的な幅を有する. そこで, 実測の回折パターンと一致させるために機械的な幅を修 正ローレンツ関数で表し ${ }^{24)}, K \alpha_{1}$ と $K \alpha_{2}$ について各 $I_{\mathrm{d}}$

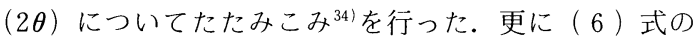

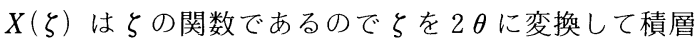
不整を有するプロファイルの計算を行った。

積層不整の影響を受けない反射の場合には（3）式あ るいは（5）式の散漫散乱項（Dv) はゼロとなり, 高 次の項のみとなる. 高次の項は以下のようなラウ工関数 となる。

$$
X(\zeta)=F(h k l)^{2} \frac{\sin ^{2} \pi N \zeta}{\sin ^{2} \pi \zeta}
$$

このラウエ関数を規格化されたガウス関数で表すと,

$$
X(\zeta)=N F(h k l)^{2} \exp \left(-\pi N^{2} \zeta^{2}\right)
$$

となる。ここで らを $c$ 軸方向におけるブラッグ条件を 満足する逆格子点の微小なずれとすると，X 線粉末法 における $2 \theta$ との間に以下のような関係がある.

$$
\zeta=2 d \sin \left(\theta+\theta_{\mathrm{b}}\right) / \lambda-2 d \sin \left(\theta_{\mathrm{b}}\right) / \lambda
$$

$\theta_{\mathrm{b}}$ はブラッグ条件を満足する反射角度である。

$\theta$ を非常に小さな値とすると

$$
\zeta=(2 d \cos \theta / \lambda) \cdot \theta
$$

となる（9) 式を（8) 式の右辺に代入して $+\infty$ まで積分すると

$$
X(\zeta)=\frac{\lambda}{2 d \cos \theta} F(h k l)^{2}
$$

となる。このような反射の場合は逆格子空間で特定の方 向に反射が伸びることなくあらゆる方向に一様に分布し ているとみなせるので（6）式の $\theta_{0}$ は 0 となる。(10) 式を（6）式に代入すると $c$ 軸方向では $c^{*}=1 / d$ であ るので，その結果，

$$
\begin{aligned}
I_{\mathrm{d}}(2 \theta) \mathrm{d} 2 \theta= & K P(2 \theta) F(h k l)^{2} \\
& \cdot \frac{R(\alpha) \lambda^{3} \Delta V \Delta l}{8 \pi r v^{2} \sin \theta \sin 2 \theta} \Omega(2 \theta)
\end{aligned}
$$

となり不整のない一般強度式に一致する ${ }^{38)} . \Omega(2 \theta)$ は 規格化された関数を表わす.

（８）式において $X(\zeta)$ をガウス関数でなくローレン ツ関数あるいは修正ローレンツ関数等の規格化関数 ${ }^{24)}$ を用いれば Rietveld 法と同等になる。しかし， Rietveld 法における $2 \theta$ 及び半価幅は単位を度で表している ので, 積層不整を含む $(6)$ 式と積層不整を含まない (11) 式を同一に扱うためには（11）式における $\Omega(2 \theta)$ 関数 の中の $2 \theta$ 及び半価幅の単位をラジアンで表現しなくて はならない. 以上のように（6）式上（11）式の単位を そろえることにより両者を同一に扱うことができる.

積層不整を有する場合でも，積層不整が小さければ積 層不整を含まない式と同様の扱いができる。例えば, Wilson ${ }^{401}$ によると積層不整の一例として不整の值が小 さいときには以下のようなローレンツ関数で

$$
D(\zeta)=12 N \alpha /\left\{9 \alpha^{2}+(4 \pi \zeta)^{2}\right\}
$$

表されるとしている．この式は（８）式をローレンツ関 数で表しただけである.ただし（12）式の中の $\alpha$ は不 整の確率を表している.（12）式の $\zeta を 2 \theta$ に置き換え れば全く（８）式と同じ展開になり, 積層不整の影響を 受ける反射から受けない反射まで統一的に処理できるこ とがわかる．すなわち Rietveld 法は積層不整の小さい 結晶のみに適していることになる，以上のことから積層 不整を有する結晶の X 線粉末プロファイルを Rietveld 法と併用することにより計算することができる.

\section{$3.2 \mathrm{SiC}$ のX線粉末プロファイルの計算法}

今回の計算は $\mathrm{SiC}$ のポリタイプのうち $2 \mathrm{H}$ と $3 \mathrm{C}$ の 間の不整の関係を検討した。このため $3 \mathrm{C}$ の結晶構造 を立方晶系から六方晶系の座標に変換して各反射の指数 及び多重度を求めた，その結果を表 1 に示す。積層不整 の種類には大きく分類して成長不整と変形不整の 2 種類 がある，層の影響度 $(g)$ が 2 以下の場合, 成長不整は

Table 1. Miller indices and multiplicities of $3 \mathrm{C}$ type $\mathrm{SiC}$ in hexagonal system.

\begin{tabular}{ccccc}
\hline $2 \theta$ (deg) & $h$ & $k$ & I (Cubic) & Multiplicity \\
\hline 35.6 & 0 & 0 & $3(111)$ & 2 \\
35.6 & 0 & 1 & $1\left(\begin{array}{lll}1 & 1 & 1\end{array}\right)$ & 6 \\
41.4 & 1 & 0 & $2(200)$ & 6 \\
60.1 & 0 & 1 & $4(220)$ & 6 \\
60.1 & 1 & 1 & $0(220)$ & 6 \\
\hline
\end{tabular}


Table 2. Lattice parameters and atomic coordinates of three basic units $(A, B, C)$.

\begin{tabular}{cccccc}
\hline \multicolumn{7}{c}{$a=3.081 \AA, c=2.516 \AA$} \\
\hline \multirow{2}{*}{ Layer } & Atom & \multicolumn{3}{c}{ Coordinate } & Temperature \\
& & $x$ & $y$ & $z$ & Factor \\
\hline \multirow{2}{*}{ A } & Si & 0.0 & 0.0 & 0.0 & 0.10 \\
& C & 0.0 & 0.0 & 0.75 & 0.10 \\
B & Si & 0.3333 & 0.6667 & 0.0 & 0.10 \\
& C & 0.3333 & 0.6667 & 0.75 & 0.10 \\
C & Si & 0.6667 & 0.3333 & 0.0 & 0.10 \\
& C & 0.6667 & 0.3333 & 0.75 & 0.10 \\
\hline
\end{tabular}

Table 3. Continuing probabilities of $\mathrm{p}$-th and $\mathrm{r}$-th layer form factors when $g=2$.

\begin{tabular}{|c|c|c|c|}
\hline $\mathrm{P}_{\mathrm{pr}}$ & $\begin{array}{ll}\mathrm{U}_{1} & \mathrm{U}_{2} \\
\mathrm{~B} & \mathrm{C}\end{array}$ & $\begin{array}{ll}U_{3} & U_{4} \\
C & A\end{array}$ & $\begin{array}{ll}\mathrm{U}_{5} & \mathrm{U}_{6} \\
\mathrm{~A}^{\mathrm{A}} & \mathrm{B}\end{array}$ \\
\hline $\begin{array}{ll}U_{1} & B \\
U_{2} & C\end{array}>A$ & & $\begin{array}{r}1-\alpha^{\prime \prime} \\
\alpha^{\prime}\end{array}$ & $\begin{array}{c}\alpha^{\prime} \\
1-\alpha^{\prime}\end{array}$ \\
\hline $\begin{array}{ll}U_{3} & C \\
U_{4} & A\end{array}>B$ & $\begin{array}{c}\alpha^{\prime} \\
1-\alpha^{\prime}\end{array}$ & & $\begin{array}{c}1-\alpha^{\prime} \\
\alpha^{\prime}\end{array}$ \\
\hline $\begin{array}{ll}U_{5} & A \\
U_{6} & B\end{array}>C$ & $\begin{array}{r}1-\alpha^{\prime} \\
\alpha^{\prime}\end{array}$ & $\begin{array}{l}\alpha^{\prime} \\
1-\alpha^{\prime}\end{array}$ & \\
\hline
\end{tabular}

$g=2$ 相当し, Wilson のモデル41) で代表される. それに 対して $g=1$ の場合は変形不整に相当し, Patersonのモ デル42)で代表される. また, 各単位層のつながりを示 す表現としてよく正順,逆順という用語が用いられるが， これは $3 \mathrm{C}$ を基準にして表すと $\mathrm{ABCABC}$ とつながる のが正順で, ACBACB とつながるのが逆順となる.

Patersonのモデルでは正順と逆順を区別し，Wilsonの モデルでは区別していない.

X 線粉末プロファイルの計算には Paterson とWilson の両モデルを用いた. 計算に使用した $\mathrm{SiC}$ の格子定数, 原子座標及び温度因子を表 2 に示す．基本単位層は表 2 の A， B，Cの 3 種類である. $g=2$ における層構造因 子の継続確率を表 3 に示す. また，このときの各層構造 因子の存在確率 $\left(\omega_{\mathrm{s}}\right)$ はすべて $1 / 6$ とした.

上記のデータを用いて以下に述べる方法で X 線粉末 プロファイルの計算を行った。まず，(003) 反射や (110) 反射のピークの形状パラメーターを粗く決める. 次に $\alpha^{\prime}$ を 0 0.5 まで 0.05 おきに変えてプロファイルを計 算し $R$ 值が最も小さい $\alpha^{\prime}$ を求める. 再度各反射の形状 パラメーターを最小二乗法により求める. 次にピーク形 状パラメーターは固定し， $R$ 值が最小になるように再 度 $\alpha^{\prime}$ の値を正確に求める. 以上のような手順により $\mathrm{SiC}$ の計算プロファイルを求めた。

\section{4. 結果と考察}

\section{1 合成温度の違いによる不整構造の変化}

\subsection{1 実測パターンの変化}

$1700^{\circ}$ から $2000^{\circ} \mathrm{C}$ までの範囲で合成した武料 T-A, B，C，Dの X 線粉末回折パターンを図 1 に示す。この 図は各温度により得られた回折パターンの最大ピーク強 度を 100 として規格化して表したものである．従来の定 性分析の方法ではこの試料に含まれる $\mathrm{SiC}$ は $3 \mathrm{C}$ を主 成分とし一部 $2 \mathrm{H}$ を含むことになる. 図 1 に示すよう に合成温度が低い場合には六方晶系表示の 3 C の (102) 反射の強度が弱くブロードで，また， $2 \mathrm{H}$ の（100）反

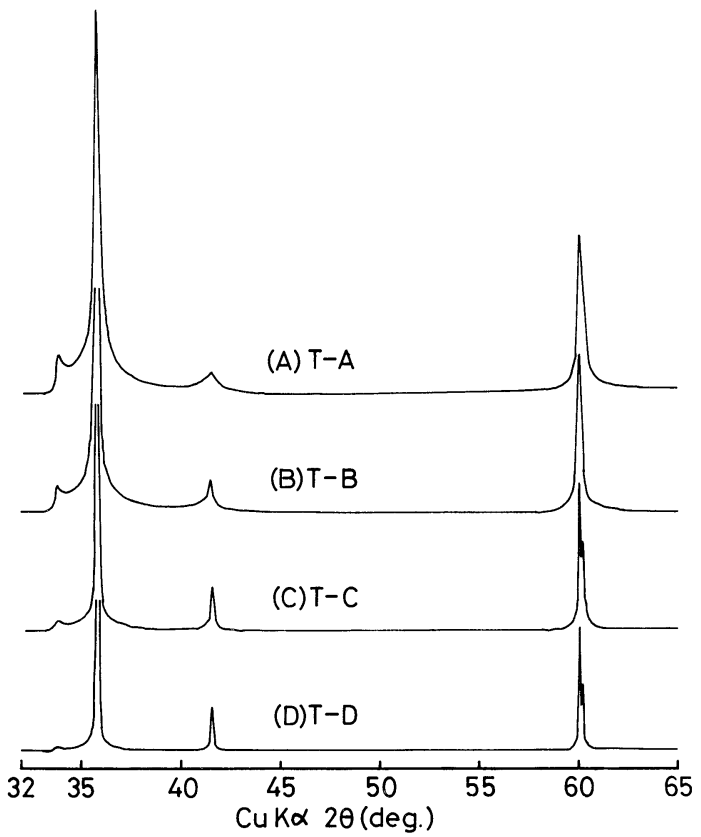

Fig. 1. X-ray powder diffraction patterns of $\mathrm{SiC}$ synthesized at different temperatures.

$\mathrm{T}-\mathrm{A}: 1700^{\circ} \mathrm{C}, \quad \mathrm{T}-\mathrm{B}: 1800^{\circ} \mathrm{C}, \quad \mathrm{T}-\mathrm{C}: 1900^{\circ} \mathrm{C}, \quad \mathrm{T}-\mathrm{D}:$ $2000^{\circ} \mathrm{C}$

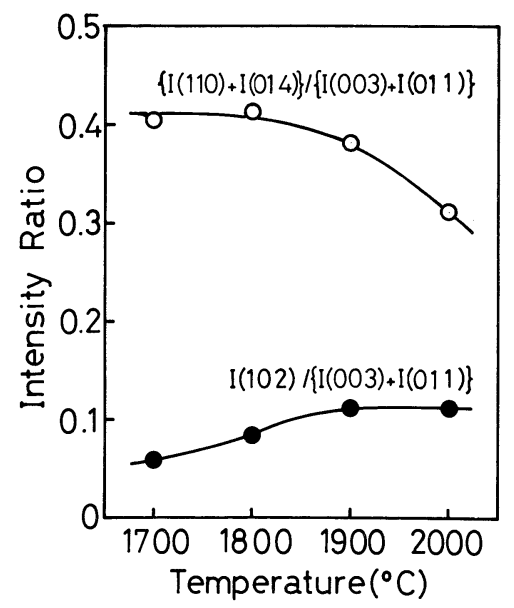

Fig. 2. Changes in intensity ratios of some reflections. 
射に相当するピークも高角度側に非対称になっている. ここで $3 \mathrm{C}$ のの反射について合成温度の変化に伴う 各反射の強度変化を図 2 に示した。ただし，この場合の 強度変化はバックグラウンドからの各反射のピーク高さ を示す. 図 2 の黒丸は $I(102) /\{I(003)+I(011)\}$ の変 化を示したものであるが，合成温度の上昇とともに徐々 に比の值が大きくなっているのがわかる．しかし白丸で 示される $\{I(110)+I(014)\} /\{I(003)+I(011)\}$ の比は $1800^{\circ} \mathrm{C}$ までは変化ないが, $1900^{\circ}$ から $2000^{\circ}$ にかけて急 激に小さくなり, $I(102) /\{I(003)+I(011)\}$ とは逆の傾 向を示した.もし結晶内に欠陥あるいは不整がないと仮 定すると, このような強度変化は考えにくいので, 合成 温度の変化に伴い結晶構造内になんらかの変化が起きて いることが予測される. 温度変化に伴う格子定数の変化 を調べるため各反射のピーク位置の測定を行った．その 結果を図 3 に示す.この図は最大強度を示すピーク位置 をプロットしたものである. 各反射のピーク位置は図 2 の結果と異なり, 図 3 に示すように (003) と (011) の

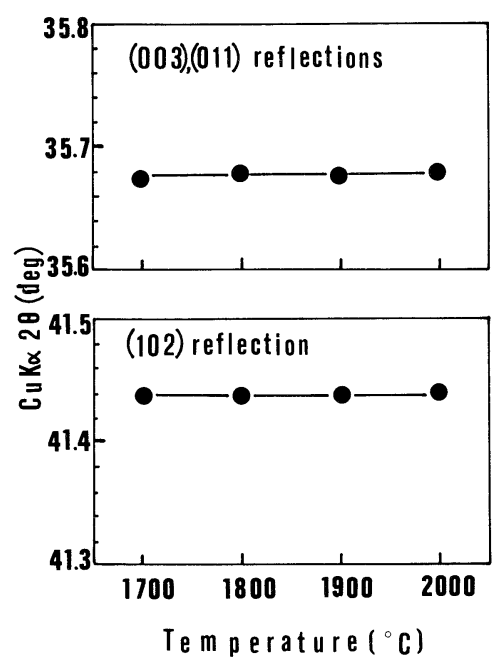

Fig. 3. Variations of peak position with increasing the synthetic temperature.

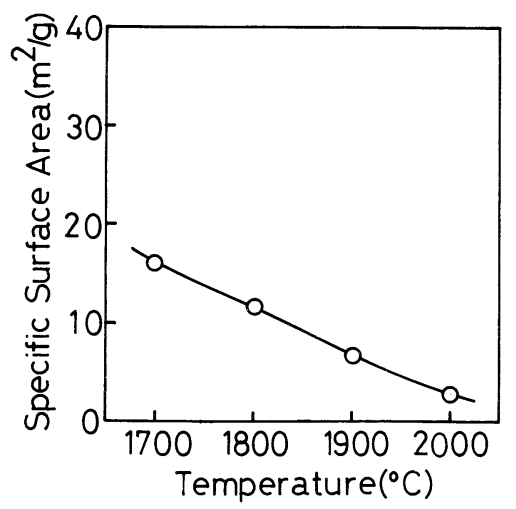

Fig. 4. Specific surface area of $\mathrm{SiC}$ at elevated temperature.
反射は温度変化でわずかに低角度側にずれるがほぼ一定 であった．また（102）反射もほとんど変化は認められ なかった. 合成温度の変化に伴う他の物性変化として比 表面積の測定結果を図 4 に示す. $1700^{\circ} \mathrm{C}$ で最も大きく, 合成温度が上昇するにつれて徐々に小さくなっている.

\section{1 .2 積層不整を考慮しない場合の X線粉末プロ ファイルの計算}

積層不整の存在を検討するため，まず積層不整を考虑 しない一般の強度式を用いて X 線粉末プロファイルを 計算し実測値との比較を行った。まず，4 試料の中から $\mathrm{T}-\mathrm{B}$ 試料を代表として選び，この試料について種々の 検討を加えた. その結果を図 5 にまとめて示す.図 5(A) は T-B の実測の X 線粉末回折パターンを示し, 図 5 (B) は結晶構造内に不整のない $2 \mathrm{H}-\mathrm{SiC}$ と $3 \mathrm{C}-\mathrm{SiC}$ の 2 種のポリタイプが混在しているものとして, 2 $\mathrm{H}-\mathrm{SiC}$ と $3 \mathrm{C}-\mathrm{SiC}$ のそれぞれの結晶構造を基に計算し たものである。実測回折パターンと計算プロファイルは 主ピークを除いてほとんど一致していない。また計算プ ロファイルの中の $2 \mathrm{H}$ の反射に相当するピークが，実 測回折パターンの位置に認められない. 以上述べたよう に合成温度の変化に伴うピーク挙動の変化並びに積層不 整を考慮しない計算プロファイルと実測回折パターンと の不一致から, 今回用いた $\mathrm{SiC}$ 粉末の試料は少なくと

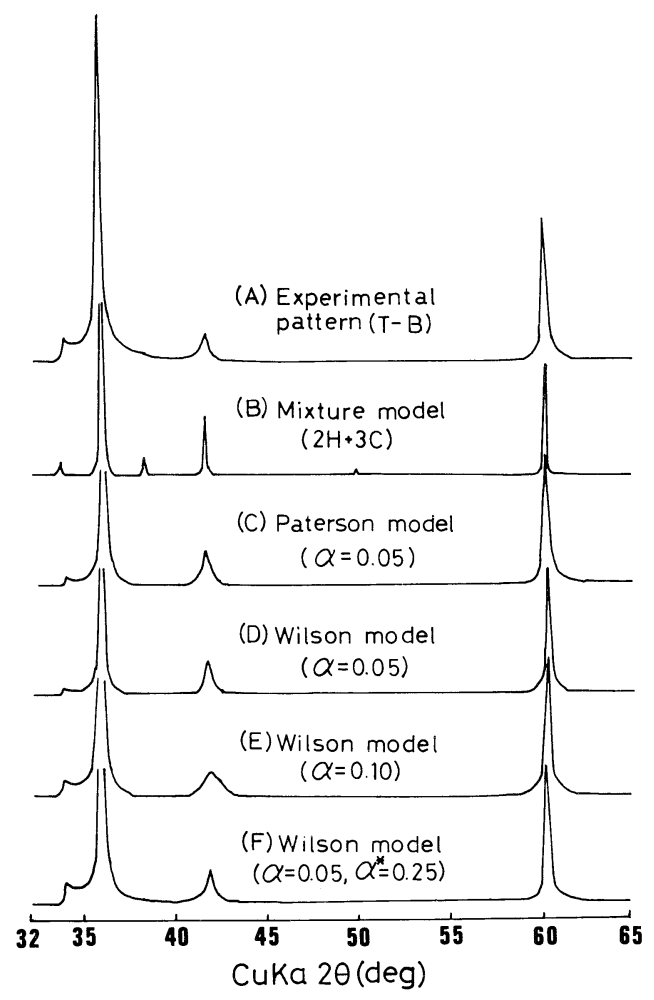

Fig. 5. Observed X-ray powder diffraction pattern of $\mathrm{T}-\mathrm{B}$ and $\mathrm{X}$-ray powder profiles calculated on the basis of Paterson and Wilson models. 
も立方晶 $(3 \mathrm{C})$ と六方晶 $(2 \mathrm{H})$ は混在しておらず， 結晶構造内に不整等のなんらかの欠陥を考慮しないと実 測パターンの説明ができないことがわかった，同様な指

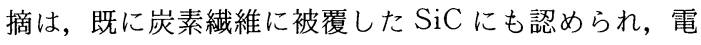
子線回折の結果から $3 \mathrm{C}$ 構造の不整とされている

これまで $2 \mathrm{H}$ 及び $3 \mathrm{C}$ の定量方法として図 2 (B) に 示した方法を基に各反射の積分強度を測定して定量する 方法が一般的に行れているが42 $\sim 43)$, 今回の試料のよう に $2 \mathrm{H}$ の反射に相当するピークが 1 本しか認められな い場合には 2 種類の結晶が混在するとは断定しにくく， 従来の積分強度を用いる方法では 3.2 節で述べた X 線 粉末法の理論式から判断して $\mathrm{SiC}$ の定量方法としては 使用することはできないことがわかった。

\subsection{3 積層不整を考慮した場合の X 線粉末プロファ イルの計算}

$\mathrm{X}$ 線粉末法の強度式に積層不整を考慮した場合， 3.2 節で述べたように層の影響度 $(g)$ が 2 以下の場合には Paterson かWilsonのモデルが適用できる．最初に Paterson のモデルについて検討した．このモデルは立 方詰め込み構造を基本にし正順のつながりの中に逆順の つながりが生じたときに不整となる。この不整の確率を $\alpha$ として, 実測パターンに一致するように $\alpha$ とピーク形 状パラメーターを種々変えて図 5 (C) に示すようなプ ロファイルを求めた？その結果，(102）反射のピーク位 置が実測値 $\left(2 \theta=41.42^{\circ}\right)$ と計算値 $\left(2 \theta=41.37^{\circ}\right)$ で異 なっていた．この傾向は $\alpha$ の増大とともに顕著になる ので, 今回の $\mathrm{SiC}$ の不整構造のモデルとしては不適当 であることがわかった。

次にWilson モデルを基に不整の検討を行った．Wilson モデルでは表 3 に示すように六方詰め込み構造を基 本にしているが，本報告では実測の X 線粉末パターン が 3 C 構造に一致するため, 表 3 に示すように立方詰 め込み構造（3C) を基本にして不整の起こる確率を $\alpha$ と表現した．すなわち， $\alpha=1-\alpha^{\prime}$ となる．3.1節で述べ た計算式を基に計算した結果を図 5 (D)，(E) に示す. (D) は $3 \mathrm{C}$ の実測の（102）反射のパターンに計算値が 最も一致するように $\alpha$ を求めたもので $\alpha$ は 0.05 であっ た。しかし， $33.5^{\circ}$ からの非対称な反射（以後プリズム 反射之呼ぶ)の強度が実測値と計算值で一致していない。 このプリズム反射に計算值が一致するように $\alpha$ を変化 させたものが図 5 （E）である．この場合（102）反射 がブロードとなるため実測值と一致しなかった，以上の ことよりWilsonのモデルでも本試料の実測パターンの 説明はできなかった。

\subsection{4 正順, 逆順を区別した場合の X 線粉末プロ ファイルの計算}

Wilson のモデルでは正順と逆順は同一の確率で生じ るという仮定がある。しかし，図 5 (D)，(E) の計算
プロファイルの変化から考えて結晶内で正順と逆順の不 整が全く同じ確率で起きているとは考えにくい，そこで 正順 $(\alpha)$ 之逆順の不整の確率 $\left(\alpha^{*}\right)$ が異なるとしてプ ロファイルの計算を行った。その結果， $\alpha$ は (102) 反 射のピークプロファイルに， $\alpha^{*}$ はプリズム反射の強度 にそれぞれ寄与していることがわかった. 3.2 節の方法 により $R$ 值が最小になるようにプロファイルを求めた 結果， $\alpha=0.05$ と $\alpha^{*}=0.25$ のときが $R$ 值が最小になっ た. 結果を図 $5(\mathrm{~F})$ に示す.またこのときの $R$ 值はバッ クグラウンドを含んだ場合は 0.17, ピークのみの場合 は 0.08 之実測值之計算值は良く一致していた。すなわ ち，この試料は立方詰め込み構造を主体にしているが正 順への不整が $5 \%$ 生じ, 逆順への不整が $25 \%$ 起きてい ることになる．結局この試料の中に含まれる不整の割合 は両者の平均值の $15 \%$ になる. 他の温度条件下で合成 した試料の計算結果を図 6 に示す. 図 1 に示した実測の プロファイルと良く一致していることがわかる.

この計算プロファイルを基に図 2 で示したのと同様の 方法で求めた $I(102) /\{I(003)+I(011)\}$ と $\{I(110)+I$ $(014)\} /\{I(003)+I(011)\}$ の比を図 7 に示す. 図 2 の実 測の結果と良く対応しているのがわかる. 更にこの計算 結果を基に求めた $\alpha$ と $\alpha^{*}$ の值を各合成温度に対してプ ロットしたものが図 8 である。合成温度が低いと $\alpha^{*}$ が 非常に大きく, 合成温度が高くなるにつれて急速に減少 している.それに対して $\alpha$ は低温でも小さな值を示し, 高温になるにつれて更に小さな值となった。

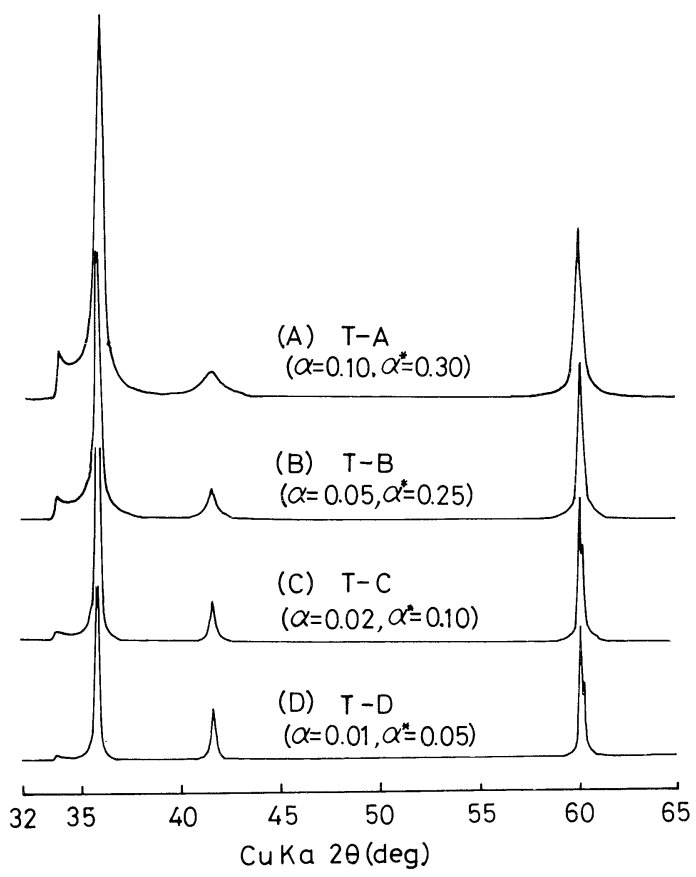

Fig.6. X-ray powder diffraction profiles calculated on the basis of the modified Wilson model. 


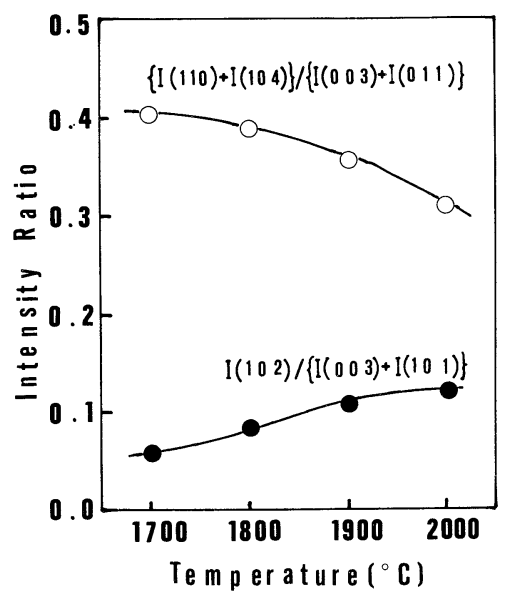

Fig. 7. Changes in the calculated intensity of some reflections.

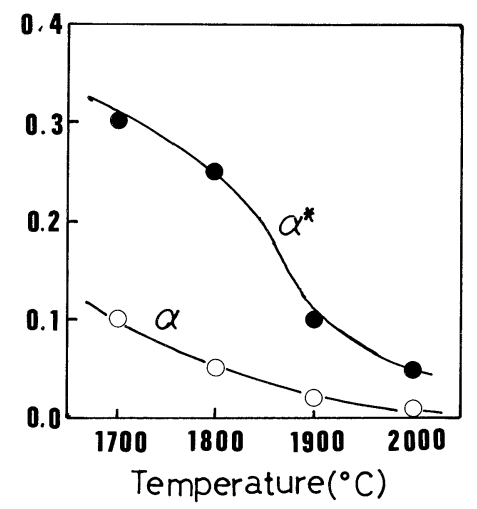

Fig. 8. Calculated probabilities of positive $(\alpha)$ and negative $\left(\alpha^{*}\right)$ sequences plotted against the temperature.

以上のように本方法で合成された $\mathrm{SiC}$ 粉末は正順と 逆順の 2 種の不整の確率が互いに異なり, かつ両不整が 全く無秩序に起きている構造を持っていることがわかっ た。また合成温度を変化させた場合, 温度が低いときに は逆順の不整が大きく, 温度が上昇するにつれてその不 整は急速に小さくなるが, 正順の不整は逆順の不整に比 較して元々少なく, 合成温度の上昇とともに更に小さく

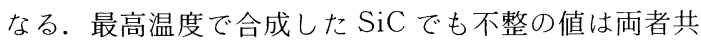
小さな值にはなるが常に逆順の不整が大きいことが明ら かになった。

\section{2 加熱による不整構造の変化}

図 9 に $1600^{\circ} \mathrm{C}$ で合成した試料を $1700^{\circ}, 1800^{\circ}, 1900^{\circ}$, $2000^{\circ} \mathrm{C}$ に加熱したときの X 線粉末回折パターン ( T-17, $-18,-19,-20)$ を示す．プリズム反射は $1700^{\circ} \mathrm{C}$ 加熱 では認められるが, $1800^{\circ} \mathrm{C}$ 以上の加熱ではほとんど認 められない。 T-17の $\alpha$ 及び $\alpha^{*}$ の值は 0.05 と 0.20 で あった。この值は, 同じ温度で合成した T-Aに比較し て小さな值を示している. また $2 \theta=38.3^{\circ}$ に $2 \mathrm{H}$ の反

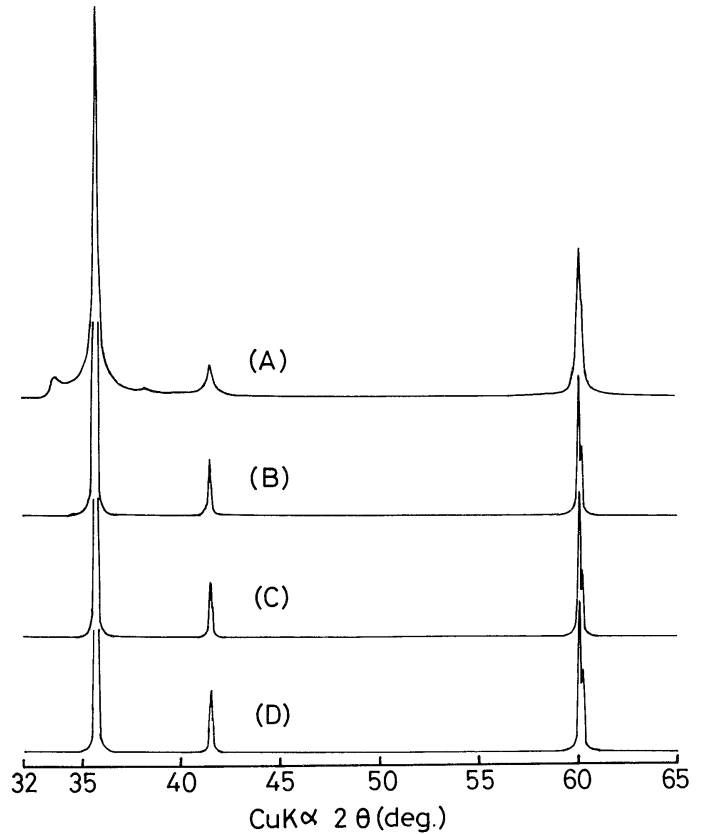

Fig. 9. Observed X-ray powder diffraction patterns of $\mathrm{SiC}$ obtained by heat treatments at each temperature.
(A) T-17,
(B) $\mathrm{T}-18$,
(C) T-19,
(D) $\mathrm{T}-20$

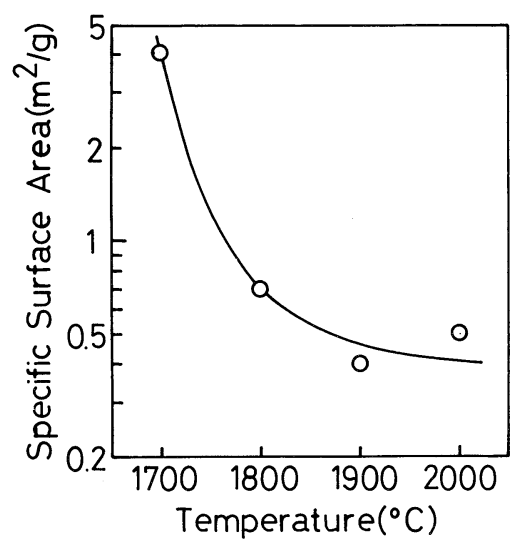

Fig. 10. Specific surface area of $\mathrm{SiC}$ obtained by heat treatment at each temperature.

射に相当する反射が非常に弱いピークではあるが認めら れる. 更に T-18 と T-B を比較しても T-Bでは不整の 存在を示すプリズム反射が認められるのに対して, T-18ではほとんどプリズム反射は認められない. T-19, T-20 と T-C, T-D を比較しても同様のことが観測さ れる. 以上のことは同じ温度で処理しても, その生成環 境によって結晶構造内に存在する不整の確率が異なるこ とを示している，不整を有する $3 \mathrm{C}$ と同時に生成して いる $\alpha$ 型 $\mathrm{SiC}$ の定量法については $g=3$ として計算す るか, または 2 種の不整の異なる結晶の混合物として定 量するかの方法が考えられるが詳しくは別に報告する. 


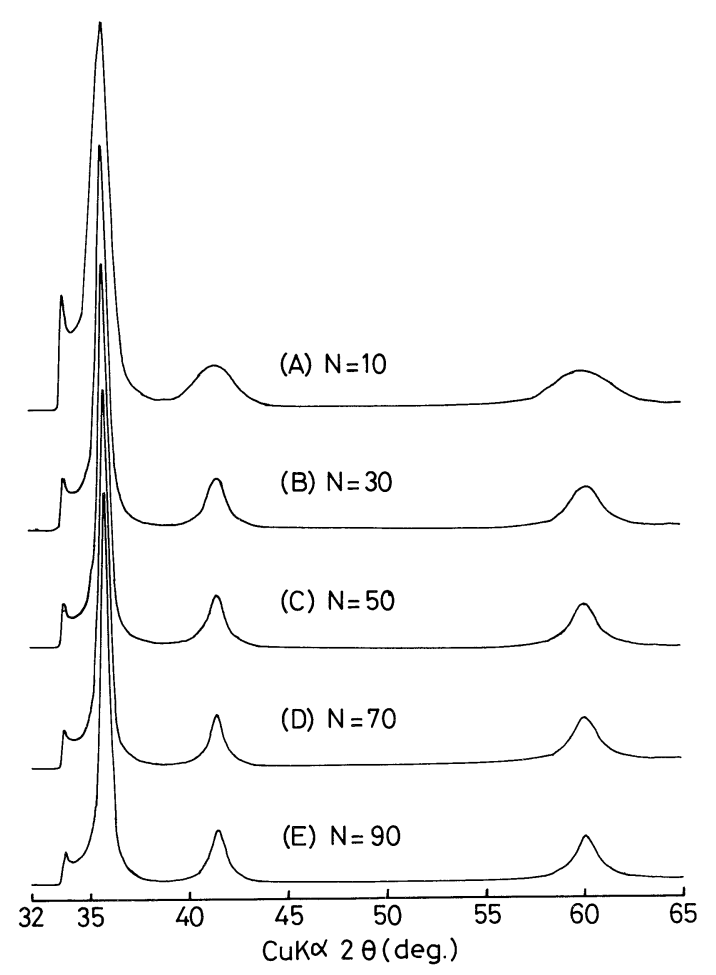

Fig. 11. Calculated X-ray powder diffraction profiles with increasing the layer number of basic unit $(N)$.

比表面積の測定結果も図 10 に示すが, 不整の確率の変 化とほぼ同様の挙動を示していた.

\section{3 結晶子の違いによる粉末プロファイルの変化}

同じ不整の確率をもつ結晶でも，結晶子の大きさに よってそのプロファイルは変化する. 図 11 に結晶子の 大きさすなわち X 線が干渉しうる層の枚数を変化させ たときの結果を示す．計算方法は 3.1 の項で述べた高次 の項を考慮して $(3)$ 式の中の層の枚数 $N$ を 10, 30, 50, 70, 90 と変化させて計算したものである. $N$ の值 が小さくなると不整の確率が大きくなったのと同じ傾向 を示している. また， $N$ が 90 以上になるとプロファイ ルはほとんど変化しなかった。ただし，この計算では不 整の影響を受けない反射は考慮していないが実際の試料 ではこの反射も $N$ の值によって変化するため, $N$ の值 を測定してプロファイルの計算に用いなければならな い. 今回測定した試料 $(\mathrm{T}-\mathrm{A}, \mathrm{T}-\mathrm{B}, \mathrm{T}-\mathrm{C}, \mathrm{T}-\mathrm{D})$ に ついて $N$ の值をシェラーの式より求めても 100 以上で あったので高次の項は考慮しなかった.しかし， $N$ の 值が 100 以下になったときには高次の項も考慮して計算 しなくてはならない.

\section{5. 結 言}

噴霧熱分解法により得た炭素と二酸化ケイ素の混合粉 末を用い各種の合成温度で超微粒の $\mathrm{SiC}$ 粉末の合成を
行った. X 線粉末法による定性分析の結果, 合成され た $\mathrm{SiC}$ にば結晶構造内に不整の存在が予測できたため, $\mathrm{X}$ 線粉末プロファイル法による積層不整を有する結晶 の構造解析を行うための基本式を検討した. その結果を 基に, 測定された全回折パターンのデータを用いて, 各 種の条件下で製造された $\mathrm{SiC}$ 粉末について不整構造の 解析を行った。 その結果を以下に要約する.

(1) 立方晶 (3 C) と六方晶 $(2 \mathrm{H})$ の理想構造を 基に Rietveld 法により合成 $\mathrm{SiC}$ 粉末について構造解析 を行った. しかし， $2 \mathrm{H}$ と $3 \mathrm{C}$ が混在しているというモ デルでは実測回折パターンとの一致が悪く, 本結晶は両 者の混合物ではないことがわかった.

（2）積層不整を考慮した式としてWilson 及び Paterson の両モデルを用いて粉末プロファイルの計算 を行った. しかし, 実測回折パターンとの一致が悪く, これらを直接適用する方法では $\mathrm{SiC}$ 粉末の不整構造の 説明はできなかった。

（3）Wilsonの方法を基に，正順と逆順の不整の確 率を異なるとして粉末プロファイルを計算した結果，実 測回折パターンとの一致が良好であった。すなわち今回 合成された $\mathrm{SiC}$ は結晶構造内で正順と逆順の不整が無 秩序に生じていることがわかった.

（4）合成温度を $1700^{\circ}$ から $2000^{\circ} \mathrm{C}$ まで変えて製造 した $\mathrm{SiC}$ 粉末の不整の確率を求めた結果, 合成温度が 低いときには正順より逆順の不整の確率が大きく, 合成 温度が高くなるに従い, 両者は急速に小さくなっていく が常に逆順の不整の確率の値が大きかった.

(5) $1600^{\circ} \mathrm{C}$ で合成した $\mathrm{SiC}$ 粉末を, $1700^{\circ}$ $2000^{\circ} \mathrm{C}$ まで再加熱した場合，（4）の結論と異なり $1800^{\circ} \mathrm{C}$ で既に正順と逆順の不整は非常に小さくなって いた.すなわち同じ温度で処理しても，その生成条件に より $\mathrm{SiC}$ の不整構造は大きく左右されることがわかっ た.

謝辞 本研究を行うに当たり，九州工業技術試験所主任 研究官・石橋 修博士には貴重な御助言を頂き, また, 同試験 所・陣内和彦資源開発部長, 広末英晴同部プロセス工学課長に はいろいろと便宜を図って頂いたのでここに感謝の意を表しま す.

\section{文献}

1）科学技術庁無機材質研究所研究報告書第 1 号 (1972) pp. 1-36.

2) 科学技術庁無機材質研究所研究報告書第 52 号 (1987) pp. 1-36.

3）長谷貞三, 鈴木弘茂, 井関孝善, 窯協, 87, 576-82 (1979).

4) D. H. Stutz, S. Prochazka and J. Lorenz, J. Am. Ceram. Soc., 68, 479-82 (1985).

5) 岡部安三, 北条純一, 加藤昭夫, 日化, 1980, 188-93.

6）木島式倫，小西幹郎，窯協，93，511-16 (1985).

7) 光井 彰, 加藤昭夫, ibid., 94, 517-20 (1986).

8) W. R. Cannon, S.C. Danforth, J.S. Haggerty and R. A. Marra, J. Am. Ceram. Soc., 65, 330-35 (1982).

9）特公昭 61-30613. 
10）特公昭 61-5647.

11）猪股吉三, 三友 護, 井上善三郎, 田中広吉, 窯協, 77, 130-35 (1969)

12) L. S. Ramsdell, Am. Mineral., 29, 431-32 (1944).

13) L. S. Ramsdell and J.A. Kohn, Acta Cryst., 5, 215-19 (1952).

14) P. T.B. Shaffer, Acta Cryst., B 25, 477-88 (1969).

15) U.S. Ram, M. Dubey and G. Singh, Zeit. für Krist., 137, 341-51 (1973)

16) U.S. Ram and G. Singh, J. Cryst. Growth, 32, 197-51 (1976).

17) Z. Inoue, J. Mater. Sci., 17, 3189-96 (1982).

18) H. Sato, S. Shinozaki and M. Yessik, J. Appl. Phys., 45, 1630-34 (1974).

19) M. Dubey, G. Singh and G. Van Tendeloo, Acta Cryst., A 33, 276-81 (1977).

20) S. Shinozaki and K. R. Kinsman, Acta Metal., 26, 769-76 (1978)

21) N. W. Jepps, D. J. Smith and T. F. Page, Acta Cryst., A 35, 916 (1972).

22) R. S. Rai, S. R. Singh, M. Dubey and G. Singh, Bull. Mineral., 109, 509-27 (1986).

23) H. M. Rietveld, J. Appl. Cryst., 2, 65-71 (1969).

24) H. Toraya and F. Marumo, Mineral. J., 10, 211-21 (1981).

25) H. Toraya, O. Ohtaka and S. Kame, ibid., 13, 500-04 (1987).

26）泉 富士夫, “X 線分析の進歩 X IV”, アグネ技術センター, 東京 (1983) pp. 43-56.

27) C.P. Khattak and D.E. Cox, J. Appl. Cryst., 10,
405-11 (1977)

28）立山 博, 陣内和彦, 石橋 修, 木村邦夫, 恒松絹江, 諫山幸男, “X 線分析の進歩 XVI”，アグネ技術センター, 東京 (1985) pp. 237-49.

29) S. Hendricks and E. Teller, J. Chem. Phys., 10, 147-67 (1942).

30) J. Kakinoki and Y. Komura, J. Phys. Soc. Japan, 7, 30-35 (1952).

31) J. Kakinoki and Y. Komura, ibid., 9, 169-76 (1954).

32) J. Kakinoki and Y. Komura, ibid., 9, 177-82 (1954).

33) M. Onoda and I. Kawada, Acta Cryst., A 36, 134-39 (1980).

34) M. Onoda, M. Saeki and I. Kawada, ibid., A 36, 952-57 (1980).

35) A. Plancon and C. Tchoubar, Clays Clay Minerals, 25, 430-35 (1977).

36）佐藤満雄, 日本結晶学会誌，17，165-80（1975）.

37）仁田勇, “ $X$ 線結晶学 (下)”, 丸善, 東京 (1961) pp. 489-715.

38）立山 博, 善協, 95, 875-81 (1987).

39) B.E. Warren, Phys. Rev., 59, 693-98 (1941).

40) A. J. C. Wilson, "X-ray Optics", John Wiley \& Sons, Inc. (1949) pp. 55-96.

41) A. J. C. Wilson, Proc. Roy. Soc., A 180, 277-82 (1942).

42) M.S. Paterson, J. Appl. Phys, , 23, 805-11 (1952).

43) K. Honjo and A. Shindo, Yogyo-Kyokai-Shi, 94, 182-88 (1986)

44) T. Kawamura, Mineral. J., 4, 333-55 (1965).

45) J. Ruska, L. I. Jauckier, J. Oreny and N. V. Poxa, J. Mater., 14, 2013-17 (1979). 